\title{
Notiser från Institutionerna för Språk och litteratur (SOL) och Kulturvetenskaper (KV)
}

Sedan bildandet av Linnéuniversitetet vid årsskiftet 2009/10 har SOL- och KV-institutionerna vid Linnéuniversitetet upplevt ett mycket verksamt år på avhandlingsfronten. Fem doktorsavhandlingar och tre licentiatavhandlingar har färdigställts och framgångsrikt försvarats.

Marie Eriksson disputerade på sin doktorsavhandling i historia, Makar emellan. Äktenskaplig oenighet och våld på kyrkliga och politiska arenor, 1810-1880 (Växjö och Kalmar: Linnaeus University Press 2010, 365 sidor). Avhandlingen analyserar den diskussion och debatt som ägde rum under 1800-talet rörande mäns våld mot sina hustrur. Studien skärskådar även de samtida normer och idéer som formade folks förståelse kring problemet, och deras förmåga att hantera det. Målet med studien är att visa hur kulturella begrepp som genus, klass, våld och maktens relationer skapades och uttrycktes under tidsperioden. Detta görs genom en undersökning av hur våldet rapporterades och behandlades såsom äktenskaplig konflikt, både på lokala religiösa arenor som kyrkmöten och i riksdagen. Resultaten av undersökningen visar att våldet mot hustrur tenderade att osynliggöras när det behandlades som en äktenskaplig konflikt på de religiösa arenorna. De kyrkliga myndigheternas mål var inte så mycket att hjälpa kvinnorna att undkomma männens våld som att bevara äktenskapets helgd. Likväl kunde kyrkan också inta en flexibel hållning och till och med agera i konflikt med lagens bokstav.

Litteraturvetaren Carl Klintborg färdigställde licentiatavhandlingen Sri Lankas historia i Michael Ondaatjes roman Anil's Ghost (Växjö och Kalmar: Institutionen för Språk och litteratur 2010, 87 sidor). Klintborg undersöker en roman från år 2000, Anil's Ghost (svensk titel, Anils skugga) av den välkände författaren Michael Ondaatje. Ondaatje är ursprungligen från Sri Lanka, och hans roman hämtar sitt tema från önationens turbulenta nutidshistoria. I romanen finns också en rad hänvisningar till äldre historia. I avhandlingen undersöks det sätt på vilket historieskrivning skildras i romantexten. Klintborg granskar vilka historiska skeenden som nämns, varför de nämns och hur de beskrivs. Frågan är här vilka samband som upprättas mellan samtiden och historien, och hur det med romanen samtida inbördeskriget på ön (som avslutades först 2009) kommer in som resonansbotten. Flera motiv i romanen återkommer i postkolonial litteratur, och diskuteras därför utifrån postkoloniala teoribildningar. Avhandlingen pekar på att den historiska kontexten är central för att förstå Ondaatjes arbete.

Roy Liddle lade fram en licentiatavhandling i engelska, Speed and time in the event modifier lexemes slow, fast and quick; A cognitive perspective (Växjö och Kalmar: Institutionen för Språk och litteratur 2010, 118 sidor). I denna grammatiska studie undersöker Liddle de händelsetyper (event types) som modifieras av lexemen långsam (slow), snabb (fast) och kvick (quick), för att förklara läsningen av dessa modifikatorer. I den språkvetenskapliga 
litteraturen talas om två-forms adverb, såsom slow/slowly eller quick/quickly, och det anses att dessa bägge lexem är tillräckligt lika varandra för att de ska vara utbytbara, och att användandet av den ena eller andra formen är upp till talaren. Grammatisk forskning har två synsätt på detta, nämligen "the meaning similarity view" och "the abstract/concrete view". Liddle vill i sin avhandling utmana dessa synsätt. Han vill visa att de studerade lexemens roll som händelsemodifikatorer är synnerligen komplexa, vilket föranleder en utförlig undersökning.

Angela Marx Åberg försvarade sin doktorsavhandling i tyska, Lesefreude und Lernerorientierung. Eine Untersuchung von Lehrentscheidungen beim Lesen eines Romans in einer Schülergruppe im schwedischen Unterricht Deutsch als Fremdsprache (Växjö och Kalmar: Linnaeus University Press 2010, 198 sidor + bilagor). I denna studie ses lärandet som en komplex beslutsfattande situation. Olika faktorer som influerar lärandeprocessen är sammanbundna och inbäddade i varandra. Målsättningen med studien är att beskriva och analysera komplexiteten i lärolitteratur i en miljö där man undervisar i ett främmande språk. Studien centrerades på en lärare och hennes grupp på 16-17 år gamla elever i en svensk gymnasieskola. Undersökningen visar att lärolitteraturen använder en beslutsfattandeprocess som är mycket komplex på grund av läsprocessens subjektiva natur. Denna komplexitet accentueras av att det är ett främmande språk som lärs ut. Elevens autonomi är ett centralt begrepp i svensk skolundervisning. Ansvaret för lärandeprocessen distribueras mellan lärare och elever. Detta ökar komplexiteten i beslutsfattandeprocessen, rörande hur man ska hantera situationer då eleven inte är beredd att ta det ansvar som givits vederbörande.

Ulf Pettersson, litteraturvetenskap, färdigställde licentiatavhandlingen Där berättelsen äger rum. Narration, perception och kognition i ett kombinerat text- och läsarperspektiv med exempel ur Eyvind Johnsons författarskap (Växjö och Kalmar: Institutionen för Språk och litteratur 2010, 107 sidor). I denna avhandling vill Pettersson koppla samman teorier och metoder som är hämtade från narratologi, modallogik samt kognitiv poetik. Med dessa utgångspunkter belyser han några aspekter på den skönlitterära prosatextens rums- och bildframkallande dimensioner, och även saker i en läsprocess som hjälper till att konstruera den värld som berättas fram. Hur kommer det sig att bokstäver, ord och meningar kan skapa mentala bilder i läsarens sinne, vilka formar en tredimensionell värld? Det underordnade syftet är att visa hur den kände svenske författaren Eyvind Johnson lyfter upp just frågan om sinnesförnimmelser och perceptionen av omvärlden, och hur han därigenom illustrerar processen.

Inom ämnet historia disputerade Tobias Stark på doktorsavhandlingen Folkhemmet på is. Ishockey, modernisering och nationell identitet i Sverige 1920-1972 (Växjö och Kalmar: Linnaeus University Press 2010, 331 sidor). Avhandlingen handlar om utvecklingen av den svenska ishockeyn såsom ett nationellt fenomen under perioden 1920-1972. Stark undersöker hur utövandet av ishockey under loppet av ett drygt halvt sekel förvandlades från en förhållandevis obetydlig nordamerikansk kulturell import till en av Sveriges mest älskade friluftssysselsättningar. Spor- 
ten kom att få ett stort intryck med landslaget Tre Kronor, som på höjden av sin popularitet kring år 1970 samlade nästan hela nationen (82 procent av den vuxna befolkningen) framför TV-apparaterna vid landskamperna. Den analytiska ansatsen baserar sig på vissa teoretiska antaganden om nationell identitet; att "vara svensk" är något som man "lär” sig på en daglig basis. En undersökning av hur "nationen” är konstruerad som en föreställd gemenskap måste se till samspelet mellan den nationella retoriken å ena sidan och nationell praxis å andra.

Historikern Johan Svanberg försvarade sin doktorsavhandling Arbetets relationer och etniska dimensioner. Verkstadsföreningen, Metall och esterna vid Svenska Stålpressnings AB i Olofström 1945-1952 (Växjö och Kalmar: Linnaeus University Press 2010, 394 sidor). Här analyseras arbetsmigration till Sverige från ett arbetareperspektiv. Avhandlingen fokuserar på intersektionen mellan klass och genus i en kapitalistisk miljö, men den ger också uppmärksamhet åt genus och ålder som strukturerande principer. Svanberg analyserar migranter som en faktor i relationen mellan arbete och kapital och undersöker hur invandringen och den aktiva rekryteringen av arbetare i andra länder påverkade, och själv påverkades av, arbetsmarknadsparternas relativa styrkeförhållande. Den tid som studeras är 1945-1952. Studien visar att Metallfacket hade stort inflytande rörande vilka företag som fick rekrytera de utländska arbetarna. Fackföreningarna kunde dirigera arbetsinvandringen till arbetsplatser med acceptabel policy. Avhandlingen diskuterar också hur sociala grupper konstruerade etniska gränser mellan "oss” och ”de andra”.

Slutligen lade Sofia Wastesson fram sin doktorsavhandling i franska med titeln $L$ 'atténuation en traduction. Étude traductologique des marqueurs de probabilité en francais et en suédois (Växjö och Kalmar: Linnaeus University Press 2010, 190 sidor). Det rör sig om en komparativ studie om hur epistemiska markörer i franska och svenska behandlas i översättningar. Studien centreras på epistemiska markörer som indikerar hög trolighet, såsom säkert, nog, jag tror (att), samt det icke-deontiska måste. På franska blir det certainement, sans doute, je crois (que), devoir, etc. Det material som används består av femton svenska romaner med franska översättningar, samt femton franska romaner med svenska översättningar. Från detta material har mer än 1500 exempel dragits, vilka visar de översättningsproblem som förekommer, bland annat rörande hur man upprätthåller talarens subjektivitet.

\section{Hans Hägerdal}

